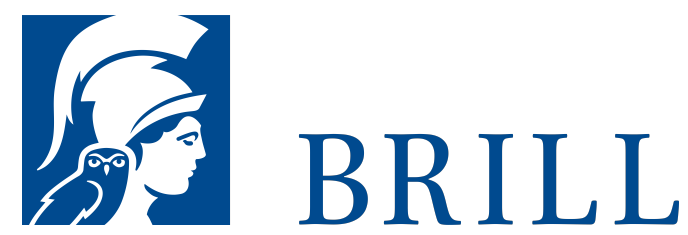

\title{
Die lutherische Reformation und der Staat
}

Author: Christian Hillgruber

Die Reformation ist zunächst eine kirchliche

Erneuerungsbewegung gewesen. Indem Luther die geistliche

Gewalt entmachtete, hat er jedoch zugleich die weltliche Gewalt außerordentlich gestärkt.

Der Reformator hat aus seinem Glaubensverständnis heraus eine spezifische Einstellung zur weltlichen Ordnung und ihrem Recht gefunden, die sehr wirkmächtig geworden ist. Ihren Mittelpunkt findet Luthers Staatsauffassung in seiner Lehre von den zwei Reichen und zwei Regimenten. Dem „Reich der Welt“ kommt dabei in erster Linie die Funktion der zwangsweisen Durchsetzung einer äußeren Rechts- und Friedensordnung zu. Eine christliche Obrigkeit hat darüber hinaus die Aufgabe einer umfassend verstandenen Gemeinwohlförderung. Dies schließt insbesondere Armenfürsorge, Krankenpflege und ein öffentliches Bildungswesen ein. Hier liegen die Anfänge des modernen Wohlfahrtsstaates.

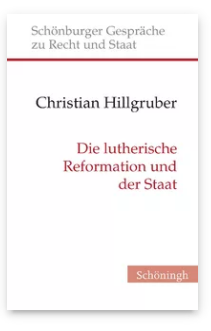

Pages: 142

Seiten

Language:

German

Subjects:

Economics \&

Political Science,

Social Sciences

Publisher: Brill |

Schöningh

Series:

Schönburger

Gespräche zu

Recht und Staat,

Volume: 29

E-Book (PDF)

Released online:

23 Oct 2017

ISBN: 978-3-

657-7886o-6

List price

Hardback

Publication date: o8 Sep 2017

ISBN: 978-3506-7886o-3

List price 
Christian Hillgruber ist seit 2002 Professor für Öffentliches Recht und seit 2016 Direktor des Instituts für Kirchenrecht an der Rheinischen-Friedrich- Wilhelms-Universität Bonn.

For more information see brill.com

Order information: Order online at brill.com +44 330 333 0049 | customerservices@brill.com Submission information: brill.com/authors

Titles published by Brill | Fink, Brill | mentis or Brill | Schöningh: +49(o)71 5413279216 | brill@brocom.de 